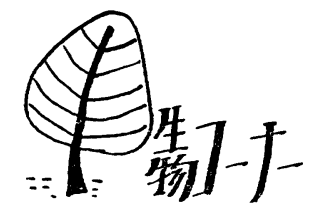

我々の生命は心臓が絶え間なく送り出す血流によって 維持されている.この心臓が規則正しいリズムで拍動を 続けていくらえで, 細胞間の情報伝達は決定的に重要な 役割を果たしている.ここでは，主として細胞培養系を 用いてわかってきた心筋細胞間の情報伝達の仕組み，な らびにこれから解明されるべき点について考えてみた い.

\section{§ 心筋細胞間における興舊伝達 §}

ヒトの心臟はおよそ 100 億という莫大な数の細胞, し かも生理学的, 形態学的に性質の異なる細胞からできて いる. 心臟が全体として統一された規則正しい拍動を行 ならことができるのは, 少なくとも次の 2 つの機構が存 在するからである，それは，(1)心臓の一部分を構成する 細胞集団にのみ自動的な規則正しい命令が発生し; (2) の命令が心臟全体に正常に伝達され，その命令に心蔵全 体が従うという機構である.

すなわち, ヒト心蔵では, 洞結節と呼ばれる細胞集団 に最初の命令が自動的に発生し, それが心房の細胞に伝

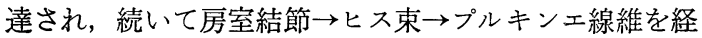

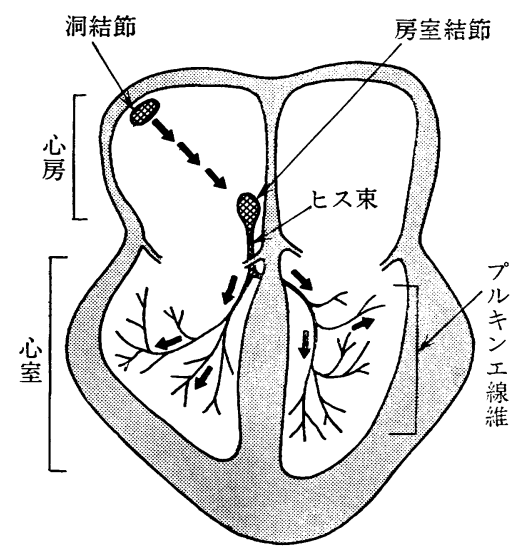

図 1 興鿖の伝達経路
て心室の細胞に伝わり（図 1)，その結果すべての心室の 心筋細胞が同期して拍動し, 強い力で血液を全身に送り 出すことができるわけである，その命令そのもの，およ び命令の伝達は，いずれも心筋細胞の電気的活動によっ て行なわれる.すなわち，命令は活動電位と呼ばれる細 胞内外に生じた電位の変化という形で発せられる. ヒト の正常心藏では，洞結節を構成している心筋細胞が自動 的に規則正しく活動電位を発生している. 命令の伝達も 次のように電気的になされる，心筇細胞間には電気抵抗 の低い接合部（ギャップ結合）があり，1つの心筋細胞 の活動電位に伴う局所電流が，その低抵抗接合部を横切 って隣の心筋細胞に伝達され，その結果その心筋細胞に 活動電位が生じるという様式で，次々と興奮伝達が行な われている。

正常な成体心臟では, 自動能は心臟の中のごく限られ た部位の心筋細胞集団（ペースメーカー部位，ヒトでは 洞結節部）にのみみられ，心房，心室の大部分を占める 収縮機能を営む作業心筋細胞には自動能はみられない。 一方，ヒト胎児，マウス胎児，ニワトリ肧などの幼若な 発生段階にある心蔵では，心房，心室から分離した心筋 細胞のほとんどのものが，自動拍動能ならびに自動的な 活動電位生成能をもっている。すなわち，これら幼若心 臓片を蛋白分解醭素（たとえばトリプシン）処理して， 1 個 1 個ばらばらの状態の細胞に分離し, 適当な培養液 を加えてシャーレに培養すると, 細胞はシャーレ底に接 着して, 自動拍動を示す.これら 1 個 1 個ばらばらの状 態の心筋細胞の自動拍動数は, 個々の細胞によってまち まちであり， $36^{\circ} \mathrm{C}$ 下で観察すると 1 分間当り $10 \sim 250$ 回の拍動を示す細胞がみられる。しかし，拍動数の異な

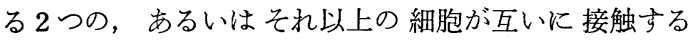
と、それらは同調した拍動をするようになる．細胞の見 かけ上の 接触から 同調化が 完了するまで 3〜38 分を要 
する. およそ 10,000 個以上の心筋細胞が互いに接触し て多細胞集合体（以下，細胞シートとよぶ）を形成する と，すべての心筋細胞は同調して拍動する．この拍動の 同調化の機構は成体心葴と同じく，心筋細胞間にギャ プ結合が形成され，その結果，興奮伝達が行なわれるこ とによることがよく知られている(1).

\section{§細胞シートは拍動の安全性の高さを支える §}

心筋細胞間に存在するギャップ結合は, 単に興奮伝達 の役割を果たすだけでなく，心蔵が不利な環境にさらさ れた場合にも，できるかぎり秩序ある拍動を維持させる よう機能している．次に，筆者らの細胞培養系を用いた 研究を紹介しよう(2).

ウアバインなどの強心配糖体の適量を超える投与が心 臓不整脈を起こすことは古くから知られている．マウス 心臟から取り出した培養下の 1 個 1 個ばらばらの状態の 細胞（単一心筋細胞）も，ウアバイン添加により不規則 拍動を行ならよらになる．不規則拍動を示す単一心筋細 胞の割合は，図2の実線で示したように，添加したウア バイン濃度の増加に伴って緩やかな曲線を描いて増加す る.このことは，単一心筋細胞の中には，低濃度のウア バインによって不規則拍動を示すようになる細胞もあれ ば，高濃度のウアバイン存在下においてすらなお規則 正しい拍動を維持できる細胞もあるといらこと，言い换 えれば，単一心笳細胞はウアバイン感受性に関して不均 一な集団であるといらことを示している.

$10^{5}$ 個以上の心筋細胞が互いに接触してできた細胞シ ートも，ウアバイン添加により不規則な拍動を示すよう になる、細胞シートの不規則拍動の様相は, ウアバイン 濃度の増加に伴って悪化する．単一細胞と細胞シートの ウアバイン不整脈の反応曲線（図 2）を比較すると， 2 つの顕著な違いが認められる１つは, シートの場合に は単一細胞の場合と異なり，ウアバイン濃度の増加に伴 って，不規則拍動を示すシートの割合が急速な立ち上が りを示す曲線を描いて増加すること，も51つは，およ そ $40 \%$ の単一細胞が不規則拍動を示す濃度のウアバイ ンの存在下に和いて，細胞シートでは規則正しいリズム の拍動を維持しらること,そして 50\% 以上の単一細胞 が不規則拍動を示すウアバイン濃度になってはじめて細 胞シートの中に不規則拍動を示すものがわずかに現われ

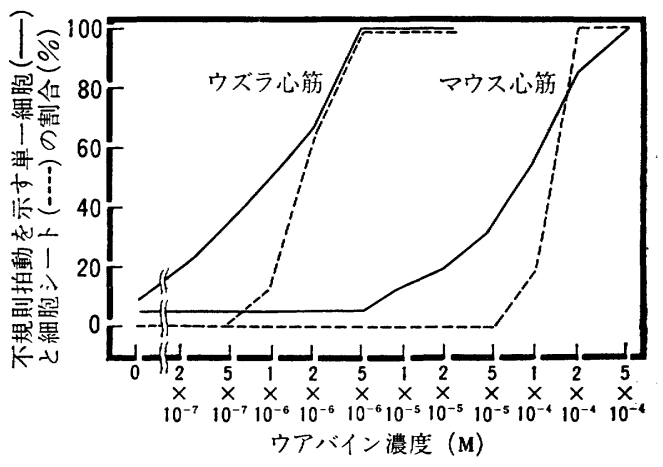

図 2 ウアバイン添加により不規則拍動を示す 単一心筋細胞ならびに細胞シートの割合

るといらことである. 同様の観察は, ウズラ心蔵から調 製した培養心筋細胞の場合にもみられる。これらの観察 は, 細胞シートは単一心筋細胞に比べて不規則拍動の状 態になりにくいといら点で, 安全性の高いシステムをつ くっていることを示している.

この細胞シートの安全珄の高さを支えている機構を考 察する前に, ウアバインの不規則拍動誘発のイオン機序 について述べておきたい。

心筋細胞内の $\mathrm{Na}^{+}$や $\mathrm{K}^{+}$のイオン濃度は, 細胞をと りまく培養液の $\mathrm{Na}^{+}$や $\mathrm{K}^{+}$のイオン濃度と著しく異な る. 細胞内では $\mathrm{K}^{+}$が多く $\mathrm{Na}^{+}$は少ない。細胞膜に は, 細胞内の $\mathrm{Na}^{+}$を能動的に細胞外へ汲み出し, $\mathrm{K}^{+}$を

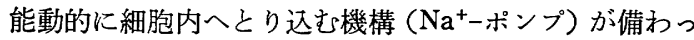
ているため, 細胞内の $\mathrm{Na}^{+}$と $\mathrm{K}^{+}$の濃度は, 外液と異 なる值に一定に保たれていることが知られている. $\mathrm{Na}^{+}$ と $\mathrm{K}^{+}$の能動輸送は, 細胞膜に存在する 酵素, $\mathrm{Na}^{+}$, $\mathrm{K}^{+}$-ATPase によって, ATP のエネルギーを使って行 なわれている，ウアバインは細胞膜 $\mathrm{Na}^{+}, \mathrm{K}^{+}-$ATPase と特異的に結合し，その酵素活性を阻害することによ り，細胞の $\mathrm{Na}^{+}$を送り出すポンプ作用を阻害すること もよく知られている. $\mathrm{Na}^{+}$ーポンプのウアバインによる 阻害，それに伴う細胞内 $\mathrm{Na}^{+}$濃度の増加と不規則拍動 の発生との間には密接な関係がある.すなわち, ウアバ イン添加により， 細胞内 $\mathrm{Na}^{+}$濃度が正常值のおよそ 1.5 倍以上になると不規則拍動が開始するのである.

\section{§ 正常拍動維持における細胞間ギャップ結合の役割 §}

さて, 多細胞シートの安全性はどのような仕組みで維 持されているのであろらか，筆者らは，培養系を使った 


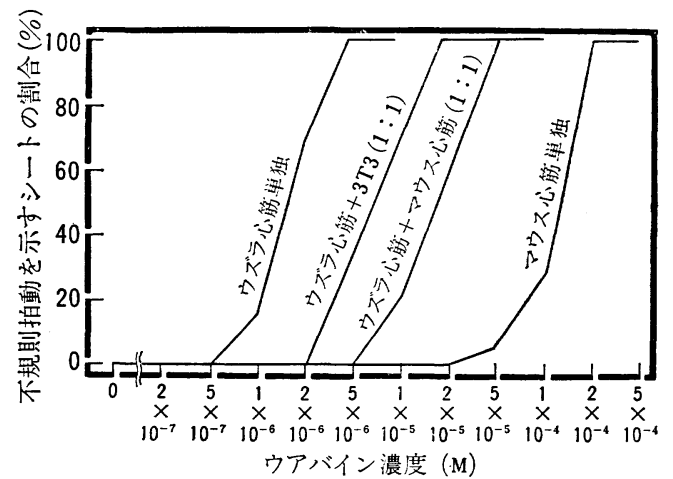

図 3 ウズラとマウスの細胞によるモザイクシートの ウアバイン感受性

モデル実験で，シートを構成している細胞のウアパイン 感受性が不均一なこと, 特よびギャップ結合を介した細 胞間の $\mathrm{Na}^{+}$の拡散に基づくことを明らかにした. 以下， この点について紹介したい,なお, ギャップ結合は分子 量 500 程度以下の分子や 1 価の陽イオンをかなり自由 に通過させる細胞間構造であり，その機能の詳細につい ては最近のすぐれた総説(る)を参照していただきたい.

ウアバイン感受性の大きく異なるマウスとウズラの心 筋細胞（図 2) を混合培養してモザイクシートをつく り，そのウアバイン感受性を検討すると，マウス細胞の 割合が増すにつれてウアバイン感受性は低くなった。 マ ウスとウズラ心筋細胞の混合比が $1: 1$ のモザイクシー トでは，そのウアバイン感受性は単独シートの感受性の ほぼ中間になった（図 3).この機構として, 次の可能性 が考えられよう、すなわら，モザイクシートを構成する 心筋細胞のうち, ウズラ由来の心筋細胞は, ある濃度の ウアバイン添加により不規則拕動を行なら状態になる が，マウス由来の心筋細胞は，その濃度のウアバイン存 在下ではなお正常な拍動ならびに正常な活動電位の発生 を行ないらる．このマウス心筇細胞の発生する正常な活 動電位が， ウズラ心筋細胞に伝達され，その結果， ウズ ラ心筋細胞にも規則正しい拍動が誘発される.

この考えによると，影響を与えるマウス心筋細胞はウ ズラ心筋細胞と接触しており, ウアバイン感受性が低 く, しかも活動電位を出す興奮性細胞に限られることに なる.しかし，次の観察は活動電位を出さない非興奮性 細胞にもそのような作用がみられることを示している. すなわち，ウズラ心筋細胞と混合する細胞としてマウス $3 \mathrm{~T} 3$ 細胞 (マウス由来の 株細胞なので, ウアバイン感

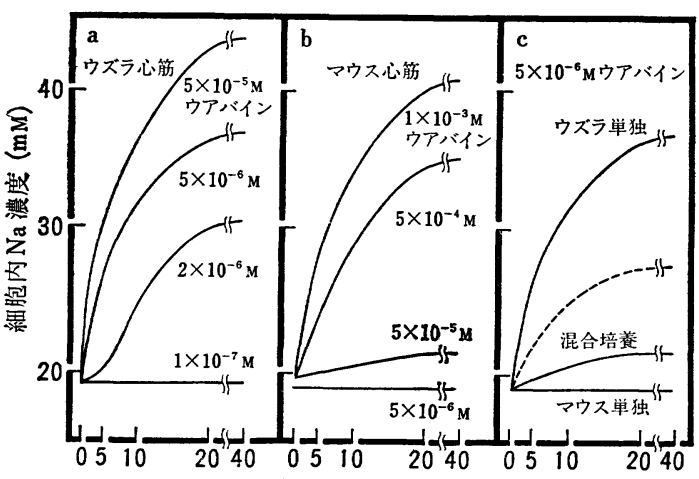

ウアバイン添加後のインキュベーション時間 (分)

図 4 ウアバイン添加によるウズラおよびマウスの 細胞内 $\mathrm{Na}^{+}$濃度の变化

受性が低くしかも非興奮性の細胞であり,さらに心筋細 胞との間に低抵抗接合をつくることのできる細胞であ る）を用いてみると，図３に示したように，3T3 細胞 と接触したウズラ心筋細胞は，ウアバインによる不規則 拍動を生じにくくなった. 一方，ニューロブラストーマ 細胞（マウス由来の株細胞であるため, ウアバイン感受 性は低いが，心筋細胞との間に低抵抗接合をつくること のできない細胞）や，FL 細胞（心筋細胞之の間に低抵 抗接合をつくることはできるが，ヒト由来の株細胞なの で, ウアバイン感受性は高い) には， 3 T 3 細胞のよう に, ウズラ心筋細胞のウアバイン感受性を低くする作用 はみられなかった。

では, ウズラ心笳細胞の拍動に対し，どのような機構 によりマウス細胞は影響を及ぼすのであろらか.

図 4 に示すように, $5 \times 10^{-6} \mathrm{M}$ のウアバイン添加によ り, ウズラ心筋細胞シートでは, 顕著な 細胞内 $\mathrm{Na}^{+}$濃 度の増加がみられるが，マウス心筋細胞内の $\mathrm{Na}^{+}$濃度 は変化していない。 また, 図 3 に示したように, $5 \times 10^{-6}$ M ウアバインの添加により, ウズラ心筋細胞シートは不 規則拍動を行なうようになるが，マウス心笳細胞シート ならびにウズラとマウス心筋細胞が 1:1 の割合で混合 されてできたモザイクシートでは，不規則拍動は生じな い. では，そのモザイクシートにおいて， $5 \times 10^{-6} \mathrm{M}$ ウ アバイン添加により細胞内 $\mathrm{Na}^{+}$濃度はどのように変化 するのであろうか. もし，1つのモザイクシート内のウ ズラとマウス心筋細胞が互いに相互作用なしにウアバイ ンに対して反応したとすると, モザイクシートの細胞内 $\mathrm{Na}^{+}$濃度は, 図 4-c の破線のように, ウズラならびにマ 
ウス心筇細胞の単独培養の中間值になるはずである、し かし，実験値はその中間値よりもはるかに低く，マウス 心筋細胞のほうにより近いことを示している。この現象 は次のイオン機序を考光れば容易汇説明できる.

モザイクシートに $5 \times 10^{-6} \mathrm{M}$ ウアバインを添加する と, ウアバインはウズラ心筋細胞の $\mathrm{Na}^{+}$ーポンプを阻害 し, その結果, ウズラ心筋細胞内の $\mathrm{Na}^{+}$濃度が増加す る. しかし，マウス心筋細胞の $\mathrm{Na}^{+}$-ポンプは正常であ る. ウズラとマゥス心筋細胞間にはギャップ結合が形成 され，そこでは $\mathrm{Na}^{+}$はかなり自由に拡散しうるので, ウズラ心筋細胞内で増加した $\mathrm{Na}^{+}$は，マウス心筋細胞 内へ拉散していく、マウス心筋細胞の $\mathrm{Na}^{+}$-ポンプは正 常作動しているので，入ってきた $\mathrm{Na}^{+}$を細胞外一汲 み出すことができる，その結果，モザイクシート全体の 細胞内 $\mathrm{Na}^{+}$濃度は低く保たれ，不規則拍動を生じるこ とはないというわけである。また，同じ動物の心臟から 調製した心筋細胞に秃いても，ウアバイン感受性は不均 一であり, ウアバイン添加によりウアバイン感受性の高 い心筋細胞内の $\mathrm{Na}^{+}$濃度が増加するが，低抵抗接合部 を横切ってその $\mathrm{Na}^{+}$はウアバイン感受性の低い心筋細 胞内に流入し，その $\mathrm{Na}^{+}$ーポンプを使って $\mathrm{Na}^{+}$を細胞外 に汲多出す。攵の結果, 細胞集団全体の細胞内 $\mathrm{Na}^{+}$濃 度は低く保たれ，不規則拍動を生じることはないという わけである。

以上の観察は，心筇細胞間に形成された低抵抗接合部 が, 単に興奮伝達の場として㗢くだけでなく, $\mathrm{Na}^{+}$など のイオンが自由に細胞間を往来できる場を提供すること により，心臟にとって不都合な状況である不規則拍動と なりにくくするということで，心臓がより安全に規則正 しい拍動を続けることができるように働いていることを 示している.

次の重要な問題は, 細胞内 $\mathrm{Na}^{+}$濃度が増加すると, どうして心筋細胞は不規則な拍動を行なうようになるか ということである. 細胞内 $\mathrm{Na}^{+}$濃度が增加すると, $\mathrm{Na}^{+}-\mathrm{Ca}^{2+}$ 交換反応に上り, 外液 $\mathrm{Ca}^{2+}$ が細胞内に入り やすくなるという機構が関与しているらしいとの知見を 得ているが，その詳細については文献2)を参照していた だきたい。
ギャッブ結合はいろいろな組織細胞間にかなり普遍的 に存在する(3). それら組織の機能を営むうえでのギャッ プ結合の役割の研究はこれからの重要な課題のひとつで あろう、筆者らは現在心拍りズムのゆらぎに対するギャ ップ結合の役割を検討中である.

1）五島喜与太 : 生体の科学, 29, 180 (1978).

2）五島喜与太, 若林繁夫: “生物リズムと生物時計”, 蛋白質 核酸醅素, 臨時增刊, 27, 170 (1982).

3）菅野義信, 柴 芳樹: 日本生理学雑誌, 47, 1 (1985).

(五島喜与太, 名古屋大学理学部)

\section{表紙写真を募集いたします}

すで御存知の上5に，1月号より本誌の表紙には写真 を揭載しております。これは，原則的汇はその号偈載の 記事に関連したものといらことになっておりますが, 読者 の方々の中には良いお写真を持持ちの方がたくさんおられ ることと存じ，今後適宜揭載させていただく予定です.

苦学して撮られたお写真, これこそ決定的眼間と自負さ れるお゙写真などありましたら，当編集部まで御連絡くださ い.なお，採否，揭載時期などについては適宜決めさせて いただきます。また，写真は原則としてモノクロに限らせ ていただきます。 